RAYHERT KONSTANTIN, Candidate of Sciences in Philosophy, associate professor, Odessa I. I. Mechnikov National University

\title{
A NEW VIEW OF REALITY (TV SERIES CULTURE STUDIES)
}

The study examines the combination of the Philip Kindred Dick's concept definition of reality and the Jakob von Uexküll's conception of Umwelt in the $2^{\text {nd }}$ episode of the $2^{\text {nd }}$ season of TV series 'Legion'. The authors of TV series 'Legion' propose an unexpected merge of the Philip Kindred Dick's definition of 'reality' and the Jakob von Uexküll's conception of Umwelt, forcing the researchers to look at reality from the surprising perspective. As a result of the combination, it's showed that the critical characteristic of the human's Umwelt is a belief of the human in the authenticity of the reality within which the human exists. The very human's Umwelt is a merger of the first Nature which is a physical one and the second Nature which is a culture; and at the same time the second Nature consists of physical (realized in the physical artifacts of culture) and virtual (realized in humans minds) dimensions. Human being depends on culture, especially on its virtual part because the very part is responsible for human language, system of signs, values and virtues and, in a certain sense, consciousness and mind, and, therefore, human relations to the external, that is, reality. In that case for human being it is crucial to have the preliminary understanding of what is real and what is not real, because its functioning, as a part of nature and a part of culture, especially society, depends on that understanding. It all attests that those two Natures determine the human's Umwelt, but if the Philip Kindred Dick's concept definition of reality is trusted, the authentic reality component part of the human's Umwelt is only the physically existed ones because only the physically existed ones don't go away if someone stops believing in them. However, there is always the fraught with danger of the falsified reality by someone who or what has power to fabricate the reality; it can be other people, something that is not people, or you.

Key words: culture; human being; nature; reality; Umwelt.

The problem statement. Certain good TV shows tend smuggling some philosophical ideas. For example, TV series 'Westworld' (2016-), created by Jonathan Nolan and Lisa Joy on basis of the Michael Crichton's film, reflects upon what it would be if the Julian Jaynes' conception of human consciousness was realized within cognitive robots with artificial intelligence. Or other TV series, 'Altered Carbon' (2018-) created by Laeta Kalogridis on basis of the Richard C. Morgan's novel, conducts a thought experiment: what would have happened if it were possible to record the human consciousness on a disk. TV series 'American Gods' (2017-), created by Brian Fuller and Michael Green on basis of the Neil Gaiman's novel, offers the idea of dependency of the existence of deities from the believing in them. TV series 'Legion' (2017-), created by Noah Hawley on basis of the comic books of Chris Claremont and Bill Sienkiewicz, is no exception.

'Legion' is a story of mutant David Haller who can warp reality, project energy, manipulate matter and energy, do telepathy, telekinesis, teleportation, pyrokinesis and travel in time. David Haller portrayed by Dan Stevens confronts other mutants, especially parasitic mutant Shadow King (portrayed by Navid Negahban) who tries bending in the David's mind and abilities, and special secret services like Division 3. Since in the TV series everything is based on the manipulations of consciousness and reality, philosophical ideas and thought experiments are often visualized there. For example, in the $9^{\text {th }}$ episode of the $2^{\text {nd }}$ season of 'Legion' there was the Allegory of the Cave invented by Plato.
Meanwhile, in spite of its "flirtation" with philosophy and unlike, for example, TV series 'Westworld', TV series 'Legion' has not caused at least the slightest interest from the professional philosophers, even from the publishers and editors of such popular book series as 'Open Court's Popular Culture and Philosophy' and 'The Blackwell Philosophy and Pop Culture' which are specialized in philosophical analysis of the phenomena of popular culture (films, TV shows, comic books, music etc.). Of course, among the fans of TV series 'Legion' there are those who are trying to discover the philosophical background, for instance: Kelly Kanayama [Kanayama, 2018] or Nick Mangione [Mangione, 2018].

To my mind, the more interesting episode of TV series 'Legion' is the $2^{\text {nd }}$ episode of the $2^{\text {nd }}$ season because there the authors of the TV series merge the Philip Kindred Dick's definition of 'reality' and the Jakob von Uexküll's conception of Umwelt. Jakob von Uexküll (1864 - 1944) was very influential German biologist and philosophers; he created biosemiotics and laid down the foundations of cybernetics of life; and also he influenced a number of philosophers such as Max Scheler, Ernst Cassirer, Martin Heidegger, Ludwig von Bertalanffy, Maurice Merleau-Ponty, Humberto Maturana, Georges Canguilhem, Michel Foucault, Gilles Deleuze and Félix Guattari [Kull, 2001], Giorgio Agamben [Agamben, 2003], Bruno Latour [Latour, 2010].

Philip Kindred Dick (1928 - 1982) is famous and cult American science fiction writer; his creative legacy is actively explored by various philosophers (e.g.: [Kucukalic, 2008; Rossi, 2011; Wittkover, 2011]). Not coincidently, 
English philosopher Simon Critchley tried to show that philosophy could be set out not only in the shape of serious academic texts but in the shape of works of fiction; this is especially the case of Philip K. Dick: "What Dick lacks in academic and scholarly rigor, he more than makes up for in powers of imagination and rich lateral, cumulative association. If he had known more, it might have led him to produce less interesting chains of ideas. In a later remark in 'Exegesis', Dick writes, 'I am a fictionalizing philosopher, not a novelist.' He interestingly goes on to add, 'The core of my writing is not art but truth'. We seem to be facing an apparent paradox, where the concern with truth, the classical goal of the philosopher, is not judged to be in opposition to fiction, but itself a work a fiction. Dick saw his fiction writing as the creative attempt to describe what he discerned as the true reality. He adds, 'I am basically analytical, not creative; my writing is simply a creative way of handling analysis'" [Critchley, 2012].

Within the context of outlined above the examination of the Philip Kindred Dick's definition of 'reality' and the Jakob von Uexküll's conception of Umwelt is very interesting, especially if this exploration will enable to move forward with the study of reality.

The purpose of the study. This study examines the combination of the Philip Kindred Dick's definition of 'reality' and the Jakob von Uexküll's conception of Umwelt.

Research and discussion. The $2^{\text {nd }}$ episode of the $2^{\text {nd }}$ season of TV series 'Legion' written by Noah Hawley, a creator of the TV series, and Nathaniel Halpern and directed by Ana Lily Amirpour contents the reasoning of what is reality. About on the $23^{\text {rd }}$ minute Narrator (voice of Jon Hamm) says: "Reality is that which, when you stop believing in it, doesn't go away". It's a direct quotation from Philip K. Dick.

In his essay 'How to Build a Universe That Doesn't Fall Apart Two Days Later' written in 1978 but published in 1985 Philip K. Dick talked about two crucial philosophical ideas of which he was concerned: 'What is reality?' and 'What constitutes the authentic human being?' There he said, "[...] over the twenty-seven years in which I have published novels and stories I have investigated those two interrelated topics over and over again. I consider them important topics. What are we? What is it that surrounds us, that we call the not-me, or the empirical or phenomenal world?" [Dick, 1996: 182]. "I wrote over thirty novels and over a hundred stories, and still I could not figure out what was real" [Dick, 1996: 183]. Philip K. Dick gave a tentative answer to question 'What is reality?': "Reality is that which, when you stop believing in it, doesn't go away" [Dick, 1996: 183]. With such an answer Philip K. Dick provides his criterion for distinguishing true (authentic) reality, such as Rene Descartes once provided his criterion 'Cogito ergo sum': the difference between Philip K. Dick and Rene Descartes is that Rene Descartes was looking for the criterion of recognition of his own reality, existence, his own identity, and Philip K. Dick was seeking the criterion of recognition of the external reality, outer world, objective reality. To put this another way, Philip K. Dick endeavored the way to fight solipsism, and Rene Descartes - quite the contrary - fought something opposite to solipsism ('anti-solipsism') because he had no doubts about the existence of the outer world since he had no doubts about the existence of the creator of the world, that is, God. For Philip K. Dick thinking, in contrast to Rene Descartes, is not necessary condition for recognition of the existence; on the contrary, thinking can play an evil trick on the human because the very thinking challenges the existence and reality. But the objective reality, even if it's imagined or thought about that it doesn't exist, does not go away. Take for example a situation when a human goes in the blind alley: he / she can imagine that there is no wall in the blind alley and the way is free but the human runs into the wall anyway - this is the reality according to Philip K. Dick.

But Philip K. Dick suspected that his criterion of reality could cast some doubts. The point is that "[...] today we live in a society in which spurious realities are manufactured by the media, by governments, by big corporations, by religious groups, political groups - and the electronic hardware exists by which to deliver these pseudoworlds right into the heads of the reader, the viewer, the listener. Sometimes when I watch my eleven-year-old daughter watch TV, I wonder what she is being taught. The problem of miscuing; consider that. A TV program produced for adults is viewed by a small child. Half of what is said and done in the TV drama is probably misunderstood by the child. Maybe it's all misunderstood. And the thing is, Just how authentic is the information anyhow, even if the child correctly understood it? What is the relationship between the average TV situation comedy and reality? What about the cop shows? Cars are continually swerving out of control, crashing, and catching fire. The police are always good and they always win. Do not ignore that one point: The police always win. What a lesson that is. You should not fight authority, and even if you do, you will lose. The message here is, Be passive. And - cooperate. If Officer Baretta asks you for information, give it to him, because Officer Baretta is a good man and to be trusted. He loves you, and you should love him" [Dick, 1996: 183-184]. As you can see, the Philip K. Dick casts doubt on his proper definition of 'reality' since there is always a chance that the real reality can be fabricated: "[...] unceasingly we are bombarded with pseudorealities manufactured by very sophisticated people using very sophisticated electronic mechanisms. I do not distrust their motives; I distrust their power. They have a lot of it. And it is an astonishing power: that of creating whole universes, universes of the mind" [Dick, 1996: 184]. The words of Philip K. Dick can be read as the words of a paranoiac: he doubts in reality because he suspects that the reality could be fabricated by someone who has power to do it. Perhaps, for Philip K. Dick someone who has power seems very dangerous; in that way Philip K. Dick most likely says that human beings are not very kind creatures in actual fact.

It should be noted that Philip K. Dick takes into account only the fact that the reality of one people may be faked by other people. However, there are other options available. Take for example the Wachowskis' film 'The Matrix' (1999) that pictures the situation within which people live in a virtual reality and don't know about the existence of the objective reality: for those people the pseudoreality precisely fits to the Philip K. Dick's definition of 'reality' people can stop believing in the pseudoreality but the pseudoreality still doesn't go away; that's why in order to make the pseudoreality disappear it needs someone from the outer world to disable from the Matrix (this is possible only if someone really is outside the Matrix; in the film there are such people, but what would they do if there weren't such people out there?).

Another option is following: a mentally ill person has hallucinatory visions - he / she sees people who do not really exist (like the character of Russell Crowe in Ron Howard's 'A Beautiful Mind' (2001)) but treatment doesn't eliminate non-existing people; consequently, the visions of non-existed people, by the definition of 'reality' given by Philip K. Dick, are that reality that does not stop its existence, when the believing in it stops. 
All said above displays that you cannot trust the definition of 'reality' given by Philip K. Dick, even if this definition seems to be very convincing.

Then, right after quoting Philip K. Dick, Narrator does an unexpected trick: "For the tick, reality is a product of temperature and butyric acid. Its perception of the world is its reality. The bloodhound has 200 million scent receptors. Its perception of the world is based fundamentally on smell. A dog doesn't reason. A tick never thinks about the universe in any way separate from its biological interactions with the universe". The talking about the tick and that the tick has its own reality is a reference to Jakob von Uexküll.

In his monograph 'A Stroll through the Worlds of Animal and Men' (1934) Jakob von Uexküll showed the specificity of the living world of an ordinary tick (next there will be a large quote): "[...] from the egg there issues forth a small animal, not yet fully developed, for it lacks a pair of legs and sex organs. In this state it is already capable of attacking cold-blooded animals, such as lizards, whom it waylays as it sits on the tip of a blade of grass. After shedding its skin several times, it acquires the missing organs, mates, and starts its hunt for warm-blooded animals. After mating, the female climbs to the tip of a twig on some bush. There she clings at such a height that she can drop upon small mammals that may run under her, or be brushed off by larger animal. The eyeless tick is directed to this watchtower by a general photo-sensitivity of her skin. The approaching prey is revealed to the blind and deaf highway woman by her sense of smell. The odor of butyric acid, that emanates from the skin glands of all mammals, acts on the tick as a signal to leave her watchtower and hurl herself downwards. If, in so doing, she lands on something warm - a fine sense of temperature betrays this to her - she has reached her prey, the warm-blooded creature. It only remains for her to find a hairless spot. There she burrows deep into the skin of her prey, and slowly pumps herself full of warm blood. Experiments with artificial membranes and fluids other than blood have proved that the tick lacks all sense of taste. Once the membrane is perforated, she will drink any fluid of the right temperature. If after the stimulus of butyric acid has functioned, the tick falls upon something cold, she has missed her prey and must again climb to her watchtower. The tick's abundant blood repast is also her last meal. Now there is nothing left for her to do but drop to earth, lay her eggs and die" [Von Uexküll, 1957: 67]. The example of the tick whose life is based nearly on temperature and butyric acid is necessary for Jakob von Uexküll to emphasize that for each animal its world depends on thing which Jakob von Uexküll called 'Umwelt', that is, environment: "[...] all animals, from the simplest to the most complex, are fitted into their unique worlds with equal completeness. A simple world corresponds to a simple animal, a well-articulated world to a complex one" [Von Uexküll, 1957: 11].

The combination of the Jakob von Uexküll's idea of Umwelt with the Philip K. Dick's definition of 'reality' may give an interesting result: reality in which an animal stops, to put it tentatively, 'believing' doesn't go away if that reality is Umwelt. Let's just imagine that the tick stops 'believing' in his reality. Whether could the tick escape his biology in that case? His biology is his Umwelt, unique world which doesn't depend on the tick's believing in it.

Nevertheless, Jakob von Uexküll showed earlier that the tick could be tricked by the researchers who had been able to reproduce for the tick the Umwelt but on other materials. Thus, the tick's Umwelt can be fabricated basically and the tick cannot tell where the real Umwelt is.
That is, the reality of the tick can be fabricated: the pseudoreality can be manufactured for the tick and the tick will percept it as an authentic reality.

The human's Umwelt is more difficult than the tick's Umwelt, and to some extent the authors of TV series 'Legion' understand it, although they never mention the word 'Umwelt': Narrator finishes with the following words: "Human beings are the only animal that forms ideas about their world. We perceive it not through our bodies but through our minds. We must agree on what is real". But why do human beings have to agree on what is real? TV series 'Legion' visualizes the answer to the question: there is a boy who was taught that red was green and green was red; as a result, this wrong knowledge turns against the boy - he sees the incorrect color signal of the traffic lights, gets across the street road and dies hit by a car. This visualization illustrates that people first and foremost depend on language: 'red' and 'green' are words, signs by means of which physical objects, phenomena, processes or their characters are being marked. Language is a system of signs; and it indicates that people are deepened into the semiosphere, a realm of signs created by the very people. This semiosphere is a part of that nature made by people, that is, culture. Umwelt of human being per se is a combination of the first, physical nature and the second nature (culture); and the latter exists either physically (in physical artifacts of culture) or virtually (in human minds). Human being depends on culture, especially on its virtual part because the very part is responsible for human language, system of signs, values and virtues and, in a certain sense, consciousness and mind, and, therefore, human relations to the external, that is, reality. In that case for human being it is crucial to have the preliminary understanding of what is real and what is not real, because its functioning, as a part of nature and a part of culture, especially society, depends on that understanding. In other words, human being needs confidence in reality for his / her survival. The very confidence in reality is only belief in the authenticity of reality within which the human being exists - this is a guarantee that the existence of the human being is authentic. Hence: the critical characteristic of the human's Umwelt is human belief in the authenticity of reality. That finding, meanwhile, is a sign which implies that the definition of 'reality' given by Philip K. Dick could be important only within the discourse of the human's Umwelt and only human's one because other living creatures are not in need for belief in reality, including the reality of selfexistence and the reality of outward things.

\section{Conclusions}

The authors of TV series 'Legion', using in the second episode of the second season of the TV series the definition of 'reality' proposed by writer Philip K. Dick and the concept of Umwelt proposed by biologist and philosopher Jakob von Uexküll, and combining them, set us thinking. The result of the combination of Philip K. Dick's definition of 'reality' and the Jakob von Uexküll's concept of Umwelt is the acceptance that the critical characteristic of the human's Umwelt is human belief in the authenticity of reality within which the human exists. The very human's Umwelt is a combination of the first, physical nature and the second nature (culture); and the latter exists either physically (in physical artifacts of culture) or virtually (in human minds). Those two natures determine the human's Umwelt, but if to trust the Philip K. Dick's definition of 'reality' the actual real component of the human's Umwelt is only that that exists physically because only that doesn't go anywhere if human stops believing in it. Nevertheless, there is always the danger that reality can be faked. 


\section{REFERENCES}

1. Agamben, G. 2003. The Open: Man and Animal. Palo-Alto: Stanford University Press.

2. Dick, P. K. 1996. How to Build a Universe That Doesn't Fall Apart Two Days Later. The Shifting Realities of Philip K. Dick: Selected Literary and Philosophical Writings. New York: Vintage, 181-196.

3. Critchley, S. 2012. Philip K. Dick, Sci-fi Philosopher. Part 1. Meditations on a Radiant Fish, available at: http:// opinionator.blogs.nytimes.com/2012/05/20/philip-k-dick-sci-fiphilosopher-part-1/.

4. Kanayama, K. 2018. Legion Season Two isn't Realistic at All, That's What Makes It Great, available at: https://nerdist.com/ legion-season-two-premiere-chapter-nine-surrealism-x-men/

5. Kucukalic, L. 2009. Philip K. Dick: Canonical Writer of the Digital Age. London: Routledge. DOI: 10.4324/9780203886847
6. Kull, K. 2001. Jakob von Uexküll: An introduction. Semiotica, No 134, 1-59. DOI: 10.1515/semi.2001.013.

7. Latour, B. 2010. Coming out as a philosopher. Social Studies of Science, No 40, 599-608. DOI: 10.1177/0306312710367697.

8. Mangione, N. 2018. The Shadow King is Still the Bad Guy on Legion, available at: https://www.geek.com/television/theshadow-king-is-still-the-bad-guy-on-legion-1738797/.

9. Rossi, U. 2011. The Twisted Worlds of Philip K. Dick: A Reading of Twenty Ontologically Uncertain Novels. McFarland: McFarland.

10. Von Uexküll, J. 1957. A Stroll through the Worlds of Animals and Men: A Picture Book of Invisible Worlds. In: C. H. Schiller (ed.). Instinctive Behavior: The Development of a Modern Concept. New York: International Universities Press, 5-80. DOI: 10.1515/ semi.1992.89.4.319.

11. Wittkover, D. E. (ed.) 2011. Philip K. Dick and Philosophy: Do Androids Have Kindred Spirits? Chicago: Open Court.

Райхерт Костянтин,

кандидат філософських наук, дочент,

Одеський національний університет імені I. I. Мечникова

\section{НОВИЙ ПОГЛЯД НА РЕАЛЬНІСТЬ (ДОСЛІДЖЕННЯ СЕРІАЛЬНОЇ КУЛЬТУРИ)}

У зв'язку з появою і постійним розвитком нових технологій, які уможливлюють виділення нових граней реальності, триває науковий пошук нових основ і характеристик, що уточнюють зміст цього поняття. У контексті такого пошуку в статті досліджується комбінація визначення поняття «реальність», запропонованого Філіпом Кіндредом Діком, і концепції Umwelt Якоба фон Ікскюля в другій серії другого сезону телесеріалу «Легіон». Автори телесеріалу пропонують несподіване поєднання визначення «реальності» Філіпа Кіндреда Діка та концепції Umwelt Якоба фон Ікскюля, змушуючи поглянути на реальність під найнесподіванішим кутом. Наслідком комбінації є те, що суттєвою ознакою людського Umwelt є людська віра в справжність реальності, в якій людина живе. Сам людський Umwelt - це об'єднання першої природи, яка має фрізичний характер, і другої природи, що є культурою, причому друга природа складається як з фізичного (реалізується в фізичних артефактах культури), так віртуального (реалізується в людській свідомості) виміру. Людина залежить від культури, особливо від їі віртуальної частини, бо ця частина відповідає за людську мову, систему знаків, цінності та, певною мірою, свідом ість і мислення, а отже, за людські відношення з зовнішнім, тобто, з реальністю. У такому випадку для людини найбільш значущим є наявність попереднього розуміння того, що реальне, а що - ні, тому що їі функціонування, як частини природи та частини культури, особливо суспільства, залежить від такого розуміння. Все це свідчить про те, що ці дві природи визначають людський Umwelt, але якщо повірити визначенню поняття «реальність», що дав Філіп КіндредДік, справжнім компонентом реальності людського Umwelt можна вважати лише те, що фізично існує, тому що лише те, що фізично існує, не щезає нікуди, якщо припинити в нього вірити. Проте завжди є небезпека підробки реальності кимось чи чимось, що спроможне підробляти реальність, будь то інші люди, нелюди чи навіть ми самі.

Ключові слова: культура; людина; природа; реальність; Umwelt.

\section{ЛІТЕРАТУРA}

1. Agamben G. The Open: Man and. Palo-Alto: Stanford University Press, 2003. 120 p. (Meridian: Crossing Aesthetics).

2. Dick P. K. How to Build a Universe That Doesn't Fall Apart Two Days Later. Dick P. K. The Shifting Realities of Philip K. Dick: Selected Literary and Philosophical Writings / ed. Lawrence Sutin. New York: Vintage, 1996. Pp. 181-196.

3. Critchley S. Philip K. Dick, Sci-fi Philosopher. Part 1. Meditations on a Radiant Fish. URL: http://opinionator.blogs.nytimes.com/2012/ 05/20/philip-k-dick-sci-fi-philosopher-part-1/ (accessed 20.05.2018).

4. Kanayama K. Legion Season Two isn't Realistic at All, That's What Makes It Great. URL: https://nerdist.com/legion-season-twopremiere-chapter-nine-surrealism-x-men/ (accessed 20.05.2018).

5. Kucukalic L. Philip K. Dick: Canonical Writer of the Digital Age. London: Routledge, 2008. 177 p. DOI: 10.4324/9780203886847

6. Kull K. Jakob von Uexkull: An introduction. Semiotica. 2001. No 134. Pp. 1-59. DOI: 10.1515/semi.2001.013.

7. Latour B. Coming out as a philosopher. Social Studies of Science. 2010. No 40. Pp. 599-608. DOI: 10.1177/0306312710367697.

8. Mangione N. The Shadow King is Still the Bad Guy on Legion. URL: https://www.geek.com/television/the-shadow-king-is-still-thebad-guy-on-legion-1738797/ (accessed 20.05.2018).

9. Rossi U. The Twisted Worlds of Philip K. Dick: A Reading of Twenty Ontologically Uncertain Novels. McFarland: McFarland, 2011. $316 \mathrm{p}$

10. Von Uexkull J. A Stroll through the Worlds of Animals and Men: A Picture Book of Invisible Worlds. Instinctive Behavior: The Development of a Modern Concept / ed. \& trans. Claire H. Schiller. New York: International Universities Press, 1957. Pp. 5-80.

11. Philip K. Dick and Philosophy: Do Androids Have Kindred Spirits? / ed. D. E. Wittkover. Chicago: Open Court, 2011. 288 p.

(C) Rayhert Konstantin

Надійшла до редакції 01.06.2018 